\title{
ODPOWIEDZIALNOŚĆ EX CONTRACTU ORGANIZATORÓW NIELEGALNEGO STRAJKU
}

\begin{abstract}
Contractual liability of illegal strike organisers

From the normative perspective illegal strike organisers are, as a rule, liable for the damages caused by that strike under the tortious liability. However, they may also be held contractually liable. This liability:

- is subsidiary in nature towards the liability resulting from the Act on Resolving Collective Disputes;

- is a private law liability regulated by the civil code and not a public law liability regulated by the Act on Resolving Collective Disputes.

De lege lata, an employer is, in principle, entitled only to make a claim against the strike organisers to pay money. The employer may oblige the striking employees to work off the time of illegal strike only in nominal working time.
\end{abstract}

Słowa kluczowe: strajk, akcje zbiorowe, odpowiedzialność deliktowa, odpowiedzialność kontraktowa, zasada zachowania pokoju społecznego

Key words: strike, collective dispute, tortious liability, contractual liability, principle of social peace preservation

\section{Wstęp}

W przypadku nielegalnego strajku, zgodnie z art. 26 ust. 3 ustawy o rozwiązywaniu sporów zbiorowych ${ }^{1}$, organizator tego protestu ponosi odpowiedzialność na zasadach

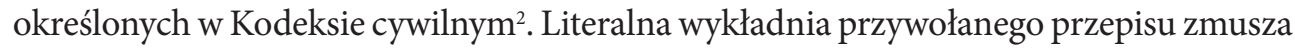

1 Ustawa z dnia 23 maja 1991 r. o rozwiązywaniu sporów zbiorowych, Dz. U. 55, poz. 236 z późn. zm., zwana dalej SporyZbior.U.

${ }^{2}$ Niniejszy artykuł stanowi rozbudowany pogląd zaprezentowany w monografii J. Żołyński, Aksjologiczne, normatywne i społeczne podstawy prawa rozwiązywania sporów zbiorowych pracy, Gdańsk 2016. 
do uznania, że odpowiedzialność ta jest wynikiem deliktu cywilnego ${ }^{3}$. Rozpatrując jednak to zagadnienie od strony aksjologicznej, a więc wartości, które powinny być chronione, sprawa przedstawia się w sposób bardziej złożony. W określonych stanach faktycznych podstawą odpowiedzialności organizatorów strajku może być szkoda będąca wynikiem nie deliktu, lecz niewykonania umowy. Niniejsze opracowanie, mające charakter syntetyczny, jest jedynie przyczynkiem do dyskusji doktrynalnej ${ }^{4}$ i próbą udzielenia odpowiedzi na pytanie o odpowiedzialność ex contractu organizatorów nielegalnego strajku za szkody nim wywołane, bez głębszej analizy niektórych pojęć, jak np. pojęcia organizator strajku, gdyż te zagadnienia były już przedmiotem badań ${ }^{5}$. Niemniej w celu udzielenia odpowiedzi w zakresie odpowiedzialności organizatorów strajku z tytułu naruszenia warunków umownych zakazu strajku niezbędne jest wyjaśnienie tzw. zasady zachowania pokoju społecznego oraz wartości chronionych w sporze zbiorowym.

\section{Zasada zachowania pokoju społecznego ${ }^{6}$}

W stosunkach społecznych zachodzących w środowisku pracy zawsze istniały, istnieją oraz będą istnieć w przyszłości różnice interesów, gdyż jest to konsekwencja relacji „kapitału” i „pracy”. (Różnice te będą dotyczyły nie tylko praw i interesów, lecz także formułowania poglądów czy zapatrywań w tym zakresie). Pomimo tych różnic w nowoczesnych i demokratycznych systemach prawnych strony zbiorowych stosunków pracy (a więc zbiorowości pracownicze i indywidualni pracodawcy oraz organizacje pracodawców) powinny układać wzajemne relacje na płaszczyźnie pokojowej koegzystencji. Od strony aksjologicznej mają bowiem wspólny cel - dobro powszechne. Służy temu zasada zachowania pokoju społecznego, która oznacza zakaz wszczynania sporów zbiorowych w przypadku obowiązywania szeroko rozumianych porozumień zbiorowych, w szczególności układów zbiorowych pracy. Jest to zatem zasada o charakterze

${ }^{3}$ W zakresie indywidualnego prawa pracy, odnośnie do odpowiedzialności kontraktowej czy deliktowej, zob. monografię A. Sobczyka, Wolność pracy i władza, Warszawa 2015, s. 167-170 i n.

${ }^{4}$ Zauważam, że w tym temacie brak jest szerszej i pogłębionej analizy zarówno doktrynalnej, jak i praktycznej.

${ }^{5}$ Przykładowo B. Cudowski, Odpowiedzialność prawna uczestników nielegalnego strajku - część I, Praca i Zabezpieczenie Społeczne 1996, 2 i część II, Praca i Zabezpieczenie Społeczne 1996, 3; B. Wagner, Odpowiedzialność za zorganizowanie i udział w nielegalnym strajku, Praca i Zabezpieczenie Społeczne 1992, 1; A. Chabrowska, Odpowiedzialność pracownika za zorganizowanie i udział w nielegalnym strajku, w: Z problematyki prawa pracy i polityki społecznej, A. Nowak (red.), t. 11, Katowice 1994; K.W. Baran, Z problematyki odpowiedzialności cywilnej za nielegalny strajk lub inną akcjęprotestacyjna, w: Prawo pracy w świetle procesów integracji europejskiej. Księga jubileuszowa Profesor Marii Matey-Tyrowicz, J. Wratny, M.B. Rycak (red.), Warszawa 2011 czy J. Żołyński, Strajk i inne rodzaje akcji protestacyjnych jako metody rozwiązywania sporów zbiorowych, Warszawa 2013.

${ }^{6}$ Analizy tej zasady szeroko dokonałem także pod innym kątem w opracowaniu Spór zbiorowy a obowiazywanie układu zbiorowego pracy. Zasada zachowania pokoju społecznego, w: Układy zbiorowe pracy. W stulecie urodzin Profesora Wactawa Szuberta, Z. Góral (red.), Warszawa 2013, s. 337-361. 
dyrektywalnym, gdyż naruszenie jej wywołuje określone skutki prawne. Celem jej jest bowiem zachowanie pokoju społecznego poprzez polubowne rozwiązywanie sporu zbiorowego przez szeroko rozumiany dialog ${ }^{7}$. Stąd powszechnie akceptowany jest pogląd, że podstawą pokojowego ładu w relacjach kapitału i pracy są demokratyczne procedury i środki służące do rozwiązywania zbiorowych sporów bez uciekania się od razu do strajku $^{8} \mathrm{w}$ rozwiązywaniu konfliktów ${ }^{9}$, poprzez prowadzenie dialogu społecznego ${ }^{10}$. Jest to także przejaw i realizacja konstytucyjnej zasady demokratycznego państwa prawa ${ }^{11}$. Państwo polskie jest bowiem $\mathrm{w}$ wymiarze globalnym dobrem wspólnym, a w wymiarze lokalnym dobrem wspólnym jest zakład pracy ${ }^{12}$. W demokratycznym państwie prawnym zabezpieczone powinny być urzeczywistnione zasady gwarantujące pokojowe rozwiązywanie konfliktów społecznych. Stąd zasada ta będzie się zatem sprowadzać do działania takich norm prawa pracy, które będą zapobiegać wywołaniu niepokojów społecznych, a tym samym będą zabezpieczać zachowanie ładu i pokoju nie tylko w relacjach pracodawca-pracownicy, lecz także poza nimi. Z założenia więc celem jej jest zapobieganie powstawaniu konfliktów społecznych w szeroko rozumianym środowisku pracy, a jeżeli już konflikty te zaistnieją, polubownym ich rozwiązywaniu, przy zastosowaniu sformalizowanych procedur opisanych w stosownych aktach prawnych. Emanacją prezentowanej zasady jest $w$ sporach zbiorowych obowiązek zachowania dialogu społecznego między partnerami społecznymi, przy założeniu, że spór zbiorowy nie może zaistnieć w przypadku obowiązywania określonych aktów autonomicznego prawa pracy (układów zbiorowych pracy czy innych porozumień). Można to określić także i w ten sposób, że normy zbiorowego prawa pracy wprowadzają określone formy postępowania

7 W literaturze przedmiotu szeroko problematykę pokoju społecznego analizuje np. A.M. Świątkowski, w monografii Gwarancje prawne pokoju społecznego w stosunkach pracy, Warszawa 2013.

${ }^{8}$ T. Zieliński, Nowy lad pracy - rzeczywistość i wizja przyszłości, w: Nowy ład pracy w Polsce i w Europie, M. Matey (red.), Warszawa 1997, s. 43.

9 Szerzej na temat rodowodu tego pojęcia, istnienia i motywacji jego utrzymania w Polsce zob. A. Świątkowski, The Social Peace Obligation During the Period of Transition from a Planned to a Market Ekonomy, w: Liber Amicorum for Clyde W. Summers. The Changing Face of Labour Law and Industrial Relations, Nemes Verlegsgessellschaff, R. Blanpain, M. Weiss (red.), Baden-Baden 1993, s. 287 i n.

${ }_{10}$ Zagadnienie to porusza między innymi B. Wypchło, Idea zachowania pokoju społecznego $w$ zbiorowych stosunkach pracy - w Polsce i w krajach demokracji zachodniej, Studia z Zakresu Prawa Pracy i Polityki Społecznej, t. I, A. Świątkowski (red.), Kraków 1994, czy tenże B. Wypchło-Grymek, Prawne uregulowania w przedmiocie sporów zbiorowych pracy a zasada zachowania pokoju społecznego, Studia z Zakresu Prawa Pracy i Polityki Społecznej, A.M. Świątkowski (red.), Kraków 1996. W przedmiocie dialogu społecznego zob. też m.in..: W. Sanetra, Dialog społeczny jako element ustroju społecznego $i$ politycznego w świetle Konstytucji RP, w: Zbiorowe prawo pracy w XXI wieku, A. Wypych-Żywicka, M. Tomaszewska, J. Stelina (red.), Gdańsk 2010 czy J. Gardawski, Na dwudziestolecie dialogu społecznego $w$ Polsce, w: Zbiorowe prawo pracy w XXI wieku, A. Wypych-Żywicka, M. Tomaszewska, J. Stelina (red.), Gdańsk 2010 czy Zakładowy dialog społeczny, J. Stelina (red.), Warszawa 2013.

${ }^{11}$ O pojęciu zasady demokratycznego państwa prawa zob. W. Skrzydło, Komentarz do art. 2 Konstytucji Rzeczypospolitej Polskiej, LEX.

12 Pojęcie wspólnoty zakładu pracy szeroko analizuję w artykule O pojęciu wspólnoty załogi w prawie pracy, Studia z Zakresu Prawa Pracy i Polityki Społecznej, K.W. Baran (red.), Kraków 2017, gdzie przywołuję również stosowną literaturę w tym zakresie. 
na wypadek aktualnie obowiązujących przepisów w zakładzie pracy, przyjętych na drodze wzajemnego porozumienia pomiędzy pracodawcą a związkami zawodowymi, będącymi reprezentacją pracowników. Zasadne jest stwierdzenie, że na gruncie ustawy o rozwiązywaniu sporów zbiorowych zasada zachowania pokoju społecznego nie jest równoznaczna $\mathrm{z}$ rezygnacją $\mathrm{z}$ prawa do strajku, lecz tylko i wyłącznie z jego czasowym ograniczeniem $\mathrm{z}$ uwagi na obowiązywanie określonych aktów prawnych ${ }^{13}$.

Organizatorzy sporu zbiorowego, a w konsekwencji strajku lub innej akcji protestacyjnej, zobowiązani są przestrzegać zasady zachowania spokoju społecznego, która sformułowana została w art. 4 ust. 2 SporyZbior.U. Z jej treści wynika, że niedopuszczalne jest wszczęcie i prowadzenie sporu zbiorowego co do treści układu zbiorowego pracy lub innego porozumienia, którego stroną jest organizacja związkowa, w przypadku obowiązywania tych aktów prawnych. Przez porozumienie, którego stroną jest organizacja związkowa, należy rozumieć wszystkie umowy, ustalenia, ugody itp., zawarte pomiędzy związkami zawodowymi i pracodawcą, w których to związki zawodowe występują w imieniu i na rzecz pracowników. Porozumienie musi mieć charakter normatywny (a nie „organizacyjny”), tzn. na jego podstawie kształtowane są wzajemnie prawa i obowiązki stron, które mogą być realizowane na drodze sądowej ${ }^{14}$. Stąd jeżeli przedmiotem sporu zbiorowego byłyby materie już objęte „uprzednio tymi ustaleniami” dokonanymi pomiędzy partnerami społecznymi, to także prowadzenie sporu w tym zakresie nie mogłoby nastąpić przed ich wypowiedzeniem. Dotyczyć to będzie zatem zarówno przywołanych układów zbiorowych pracy, jak i szeroko rozumianych regulaminów wynagradzania (premiowania czy nagradzania). Na tym tle sporny jest charakter tzw. pakietów socjalnych, które są zawierane z reguły pomiędzy związkami zawodowymi z jednej strony a inwestorem wraz $\mathrm{z}$ dotychczasowym pracodawcą z drugiej strony. Są to jednak, jak wskazano powyżej, „porozumienia, którego stroną jest organizacja związkowa” oraz nie są to porozumienia o charakterze „organizacyjnym”. Z tego też względu związek zawodowy, który zamierzałby wszcząć spór zbiorowy w tym zakresie, zobligowany byłby również zastosować te same warunki i procedury, jak przy innych porozumieniach.

Dyrektywa zachowania pokoju społecznego jest gwarantem innej zasady, a mianowicie zasady pacta sunt servanda. Jeżeli strony zbiorowych stosunków pracy „umówiły” się co do obowiązywania określonych aktów autonomicznego prawa pracy, to przez okres ich obowiązywania nie będą na ich tle wszczynały sporów zbiorowych. Tym samym umawiające się strony każdego porozumienia zobowiązują się w pełni respektować przyjęte rozwiązania, co oznacza, że wprowadzają ład i zapewniają porządek prawny w zakładzie pracy. Oczywiście, żaden akt prawny nie jest wieczny, gdyż jeżeli którejś ze

${ }^{13} \mathrm{~W}$ nieco innej postaci podobną tezę formułuje A. Świątkowski, The Social Peace..., s. 292 i n.

${ }_{14}$ Problematykę tę szerzej analizuje J. Żołyński, Porozumienia kończace spór zbiorowy jako „swoiste” źródła prawa pracy, Studia z Zakresu Prawa Pracy i Polityki Społecznej, A. Świątkowski (red.), Kraków 2013. 
stron (pracodawcy lub związkom zawodowym) przyjęte akty prawne już nie odpowiadają, to mogą je wypowiedzieć. Do czasu utraty ich mocy prawnej powinny być jednak respektowane ${ }^{15}$.

Zasada zachowania pokoju społecznego, zwana także systemem no-strike (lub ograniczeniem ratione temporis) albo obowiązkiem zachowania pokoju społecznego (peace obligation), jest uznaną i w zasadzie ${ }^{16}$ powszechnie akceptowaną normą w wielu państwach europejskich i służy zachowaniu pokoju społecznego w stosunkach pracy ${ }^{17}$. Nie jest więc rozwiązaniem funkcjonującym jedynie w prawie polskim ${ }^{18}$. Zapoczątkowana została w Niemczech ${ }^{19}$ (niem. die Friedenspflicht $)^{20}$ i następnie przyjęły ją inne państwa demokracji zachodniej. Zasada ta obejmuje spory, skierowane przeciwko obowiązującym układom zbiorowym pracy w całości lub przeciwko ich postanowieniom, tzn. te, które dążą do usunięcia lub zmiany obowiązujących układów zbiorowych pracy. W Niemczech ${ }^{21}$, podobnie jak w Polsce, uznaje się, że w przypadku obowiązywania w układzie regulacji płac wystąpienie z postulatem podwyższenia wynagrodzenia narusza obowiązek zachowania pokoju w zbiorowych stosunkach pracy ${ }^{22}$. Złamanie

15 Osobnym zagadnieniem jest brak zapisów umożliwiających dokonanie wypowiedzenia porozumień zawartych na czas nieokreślony. W tym względzie należy zwrócić uwagę na precedensowy, który zasługuje w pełni na akceptację, wyrok SN z dnia 5 listopada 2015 r., III PK 26/15 (http://www.sn.pl/sites/ orzecznictwo/Orzeczenia3/III\%20PK\%2026-15-1.pdf; dostęp: 14.03.2018), gdzie w uzasadnieniu uznano, że: „Dopuszczalne jest usprawiedliwione obiektywnymi okolicznościami wypowiedzenie porozumienia kończącego zakładowy spór zbiorowy (na podstawie art. $365^{1} \$ 1$ kc w związku z art. 300 Kodeksu pracy (kp), wynikające z postanowień rozwiązanego porozumienia zbiorowego lub per analogiam do art. $241^{7}$ kp), a w konsekwencji legalne i usprawiedliwione jest dokonanie indywidualnych wypowiedzeń warunków pracy i płacy, które były oparte lub wynikały z rozwiązanego z upływem okresu wypowiedzenia zbiorowego porozumienia prawa pracy inkorporowanego do treści indywidualnych umów o pracę”.

16 Obowiązek zakazu wszczynania i prowadzenia strajku w okresie obowiązywania układu zbiorowego pracy nie jest uznawany np. we Włoszech, gdzie uznaje się, że zakaz „zrzeczenia się prawa do strajku” jest nielegalny, R. Birk, Industrial Conflict. The Law of Stres and Lock-out, w: Comparative Labour Law and Industrial Relations, R. Blanpain (red.), Deventer, The Netherland 1985, s. 413.

$17 \mathrm{Na}$ temat tzw. umów rozjemstwa szeroko wypowiedziano się w piśmiennictwie zachodnim, np. M. Franzen, Erfurter Kommentar zum Arbeitsrecht, Munchen 2012, s. 2647 czy F. Gamillscheg, Kolletives Arbeitsrecht. Ein Lehrbuch. Band I: Grundlagen/Koalitionsfreiheit/Tarifvertrag. Arbeitskampf und Schlichtung, Munchen 1997, s. 1076 i n.

18 W zakresie praktyki państw obcych odnośnie do klauzuli pokoju społecznego zob. m.in. monografię A.M. Świątkowskiego, Gwarancje prawne pokoju społecznego...

19 B. Wypchło, Idea zachowania pokoju społecznego..., s. 358.

${ }_{20} \mathrm{~W}$ przedmiocie rozwiązań niemieckich zob. K. Kloc, Konflikty przemysłowe, spory zbiorowe i mediacje, w: Zbiorowe stosunki pracy w Polsce w perspektywie integracji europejskiej, W. Kozaczek (red.), Warszawa 1997.

21 Szerzej na ten temat W. Schülter, Prawo zbiorowych sporów pracowniczych w RFN, Studia Prawnicze $1991,1$.

22 Mechanizm ten znany jest także w wielu krajach zachodnich i służy zagwarantowaniu pokoju społecznego, który polega m.in. na zawieszeniu prawa do strajku. Szerzej zob. B. Wypchło, Idea zachowania pokoju społecznego..., s. 358 i n. Inny system, tzw. cooling of period („okres ostudzenia namiętności”), spotykany głównie w USA, Japonii i niektórych państwach skandynawskich, sprowadza się do zawieszenia prawa do strajku przez organa państwa w określonym czasie. 
pokoju społecznego w okresie dwudziestolecia międzywojennego traktowane było przez państwa europejskie jako działanie przeciwko układom zbiorowym pracy ${ }^{23}$. Stąd obowiązek zachowania spokoju społecznego trwa tak długo, jak długo strony są związane układem lub innym porozumieniem zbiorowym ${ }^{24}$. Tym samym strony układu dzięki temu wyrażają szacunek dla uzgodnionych przez siebie norm. Powinność przestrzegania wskazanej zasady wynika także z norm prawa międzynarodowego - z Europejskiej Karty Społecznej z 18 października 1961 r. ${ }^{25}$ Zgodnie z art. 7 ust. 4 karty prawo prowadzenia sporów, w tym strajku, jest dopuszczalne z zastrzeżeniem zobowiązań, jakie mogłyby wyniknąć z wcześniej zawartych układów zbiorowych pracy. Procedura prowadzenia sporu powinna być zatem poprzedzona wypowiedzeniem układu.

W celu zobrazowania przedmiotowej problematyki pokażemy, jak w niektórych krajach wygląda ta zasada ${ }^{26}$.

1. We Francji prawo do strajku zagwarantowane jest konstytucyjnie. Obowiązek zachowania pokoju społecznego może być formułowany jako tymczasowa rezygnacja, chwilowe zrzeczenie się prawa do strajku. Partnerzy umów zbiorowych nie mogą przedsięwziąć żadnych działań w czasie obowiązywania układu, które mogłyby przeszkodzić w lojalnej realizacji zobowiązań. Obowiązek zachowania pokoju społecznego ma zatem charakter względny.

2. Idea zachowania pokoju społecznego uzyskała specyficzną ochronę we Włoszech na początku wieku XX. Sprowadzała się ona do tego, że na związek zawodowy nałożono obowiązek złożenia do depozytu określonej kwoty w celu zagwarantowania wypełnienia układowych zobowiązań. Tego typu klauzula no-strike znalazła swoje odzwierciedlenie następnie w wielu układach zbiorowych. Obowiązek zachowania pokoju społecznego we Włoszech miał więc charakter relatywny.

3. Z kolei w Stanach Zjednoczonych występuje cała hierarchia klauzul zakazujących strajku o różnym stopniu nasilenia tego zakazu. Decydujące znaczenie ma faktyczna pozycja związków zawodowych z jednej strony i pracodawców z drugiej strony. W sytuacji gdy związki zawodowe są silne, $z$ reguły umowa zbiorowa nie przewiduje żadnych ograniczeń do strajku. Z kolei gdy mocną pozycję posiada pracodawca, klauzula no-strike może mieć nawet w skrajnej postaci charakter absolutny w ogóle strajku nie usprawiedliwiają nawet nieusprawiedliwione i krzywdzące pracowników praktyki dokonywane przez pracodawców. Przykładowo stosowana jest w państwowym sektorze instytucja arbitrażu z jednoczesnym zakazem strajku i lokautu. Jest to tzw. grives arbitration - proces zbierania zarzutów i kolektywnego udowadniania racji, połączony z obowiązkiem zachowania pokoju oraz poprzedzony zwykle negocjacjami, które mogą zakończyć się arbitrażem. W tym czasie

${ }^{23}$ A.M. Świątkowski, Gwarancje prawne pokoju społecznego..., s. 44.

${ }^{24}$ W. Masewicz, Ustawa z dnia 23 maja 1991 r. o rozwiązywaniu sporów zbiorowych. Komentarz, Warszawa 1992, s. 20.

${ }^{25}$ Europejska Karta Społeczna z dnia 18 października 1961 r. Dz. U z 1999 r., Nr 8, poz. 67.

${ }^{26} \mathrm{Za} \mathrm{B}$. Wypchło, Idea zachowania pokoju społecznego..., s. 358-360. 
podejmowanie akcji protestacyjnych jest zakazane. Stan ten prawdopodobnie jest wynikiem obowiązywania w USA szeroko rozumianej wolności i swobody w zakresie nawiązania, rozwiązania i kształtowania stosunków pracy, wyrażającej się m.in. w koncepcji employment at will, która uznaje, że każda ze stron stosunku pracy ma prawo dowolnie zerwać umowę, na podstawie „dobrego powodu, złego powodu albo bez powodu"27.

4. W niektórych państwach, np. w Szwecji ${ }^{28}$, można spotkać klauzule nakładające absolutny obowiązek zachowania pokoju społecznego poprzez przyznanie pracodawcy uprawnień do jednostronnego rozstrzygania spraw nieuregulowanych układem, aż do czasu jego wygaśnięcia.

5. W Wielkiej Brytanii klauzule no-strike były często stosowane, choć nie miały ściśle wiążącego charakteru. Prawdopodobnie z uwagi na obowiązujący tam system common law były to raczej umowy honorowe i traktowano je jako wyraz dobrej woli i wzajemnego zaufania.

Przywołanie regulacji obowiązujących w innych krajach upoważnia do stwierdzenia, że na świecie w zasadzie do utrzymania pokoju społecznego służą różne formy i instytucje. W szczególności należą do nich:

- układy zbiorowe pracy;

- wewnętrzne reguły związkowe;

- klauzule typu no-strike, klauzule rozejmowe (rozjemcze);

- generalna zasada pacta sunt servanda;

- tzw. niewidzialne klauzule, np. zasady prawa ${ }^{29}$.

\section{Wartości chronione w trakcie strajku}

W celu ustalenia odpowiedzialności organizatorów nielegalnego strajku, konieczne jest co najmniej w zarysie określenie od strony aksjologicznej wartości, które powinny być w strajku (sporze zbiorowym) chronione. Ustalenie aksjologii ochrony wartości w sporze zbiorowym jest bowiem kluczowym elementem do usunięcia wielu wątpliwości dotyczących wykładni przepisów o rozwiązywaniu sporów zbiorowych. Pozwala mianowicie na rozstrzygnięcie istotnego elementu, jakim jest określenie charakteru prawnego tej ochrony. Nie jest bowiem możliwe dojrzałe analizowanie danej instytucji bez przyjęcia założeń co do jej charakteru ${ }^{30}$. Ponadto odpowiedzi udzielone na pytanie, jakie wartości chronione są w trakcie sporu zbiorowego (strajku), będą stanowić podstawę

${ }^{27}$ W. Świda, Koncepcja „employment at will" w federalnym prawie pracy Stanów Zjednoczonych Ameryki Pótnocnej. Studia z Zakresu Prawa Pracy i Polityki Społecznej, A. Świątkowski (red.), Kraków 2006, s. 269.

${ }^{28}$ Klauzula pokoju społecznego obowiązująca w Szwecji zabrania organizowania strajków w czasie obowiązywania układu zbiorowego pracy, A. Świątkowski, Rozwiązywanie sporów zbiorowych. Studia z Zakresu Prawa Pracy i Polityki Społecznej, Kraków 1994, s. 320.

${ }^{29}$ B. Wypchło, Idea zachowania pokoju społecznego..., s. 358.

${ }^{30}$ Myśl zaczerpnięta od A. Sobczyk, Wolność..., s. 167. 
do wyjaśnienia, dlaczego sprawca naruszenia niektórych wartości ponosi z tego tytułu odpowiedzialność. Brak przywołania wartości chronionych w sporze zbiorowym czyni niemożliwym od strony konstrukcyjnej zastosowanie określonej odpowiedzialności cywilnej (a nawet karnej czy pracowniczej).

W sporze zbiorowym niewątpliwie podstawową wartością chronioną, jak zresztą i w indywidualnym prawie pracy, jest wolność pracy, gdyż wolność pracy jest „prawniczą emanacją wolności od wykluczenia społecznego" ${ }^{31}$. Jest to - moim zdaniem - nie tylko wolność pojmowana w kategoriach prawa prywatnego, co jest oczywiste, lecz także należy ona do sfery prawa publicznego, choć brak jest de lege lata publicznoprawnych regulacji nakazujących podjęcie szeroko rozumianego zatrudnienia ${ }^{32}$. Innymi wartościami chronionymi w sporze zbiorowym są niewątpliwie m.in.: dialog społeczny, niezależność partnerów społecznych, etyka pracy, solidarność społeczna, ochrona przed wykluczeniem społecznym czy, co rzadko się eksponuje, ochrona własności pracodawcy. Rozpatrując zatem przedmiotową problematykę, wywód logiczny wymusza uznanie, że ochrona niektórych wartości ma charakter publiczny, a niektórych wybitnie prywatny. Otóż charakter prywatny będzie miała ochrona dóbr w postaci ochrony godności, własności czy zakazu naruszenia innych dóbr osobistych. Z kolei za dobra publiczne należy uznać ochronę takich wartości, jak pokój społeczny, dialog, bezpieczeństwo socjalne czy bezpieczeństwo państwa.

Rozpatrując niniejsze zagadnienie, nieodzowne jest odwołanie się do funkcji sporu zbiorowego. Otóż funkcją sporu zbiorowego jest:

- z jednej strony, walka o utrzymanie lub zmianę na korzyść interesów zbiorowości pracowniczej;

- z drugiej strony, w przeciwieństwie do funkcji indywidualnego prawa pracy, którą jest ochrona standardów pracy, ex generali ochrona miejsc pracy jako źródła utrzymania pracowników i ich rodzin, a poniekąd zachowania pokoju społecznego.

\section{Odpowiedzialność ex contractu}

Ustawa o rozwiązywaniu sporów zbiorowych normuje podstawy odpowiedzialności na zasadach Kodeksu cywilnego, a więc według reguł cywilnych jest to odpowiedzialność na zasadach ex delicto lub ex contractu. Ogólnie odpowiedzialność ta ma w praktyce charakter odpowiedzialności deliktowej, gdyż przywołana ustawa dotyczy strajku

31 Tamże, s. 298.

${ }^{32} \mathrm{~W}$ poprzednim systemie prawnym za przykład może posłużyć Ustawa z dnia 7 marca $1950 \mathrm{r}$. o zapobieganiu płynności kadr w zawodach lub specjalnościach szczególnie ważnych dla gospodarki uspołecznionej, Dz. U. z 1950 r., Nr 10, poz. 107. Zawierała ono w sobie wyraźnie wymiar publiczny z silnie zaakcentowanym pierwiastkiem administracyjnym, gdyż zgodnie z tym aktem prawnym właściwe organy państwa wydawały nakazy administracyjne dotyczące zatrudnienia, a ich niewykonanie egzekwowane było w postaci sankcji administracyjno-karnej. 
przeprowadzonego niezgodnie $\mathrm{z}$ tym aktem prawnym, a więc strajku o charakterze nielegalnym. Strajk będący akcją legalną w rozumieniu przywołanej ustawy inkluduje implicite na podstawie art. 26 ust. 3 Spory.Zbior.U. do systemu zbiorowego prawa pracy kontratyp zwalniający organizatorów od odpowiedzialności cywilnej za szkody będące jej konsekwencją. Warunkiem wyłączenia odpowiedzialności jest więc bezwzględne respektowanie wszystkich ustawowo zadekretowanych przesłanek i procedur określających organizację strajku. Stąd naruszenie jakichkolwiek regulacji normatywnych skutkuje aktualizacją odpowiedzialności cywilnej organizatora ${ }^{33}$. Z tego też względu, w przypadku wyrządzenia szkody pracodawcy w wyniku nielegalnej akcji strajkowej, jej organizatorzy ponoszą odpowiedzialność na zasadach przewidzianych w Kodeksie cywilnym (kc). Będzie to zatem odpowiedzialność deliktowa, gdyż jest to czyn niedozwolony - art. 415 kc (kto ze swojej winy wyrządził szkodę, winien jest jej naprawienia) lub art. $416 \mathrm{kc}^{34}$ (osoba prawna zobowiązana jest do naprawienia szkody wyrządzonej przez jej organ). Nie ma znaczenia, czy wina ta miała charakter winy umyślnej, czy też nieumyślnej. Rzecz ta jest oczywista i nie wymaga dalszej analizy zarówno teoretycznej, jak i normatywnej. W tym też względzie należy zaznaczyć, że unormowania zawarte w ustawie o rozwiązywaniu sporów zbiorowych dotyczące deliktu są przejawem regulacji z zakresu publicznoprawnego, w którym występują elementy o charakterze społecznym. Celem ich jest przeciwdziałanie niekontrolowanym aktom niepokojów społecznych w zakładzie pracy poprzez usankcjonowanie stosownej odpowiedzialności odszkodowawczej za „żywiołowe” akcje protestacyjne.

W przypadku wszczęcia sporu zbiorowego i następnie strajku powstaje jednak istotne pytanie, czy należy rozpatrywać nielegalność strajku wyłącznie w kategoriach regulacji ustawowej, czy też można ją także rozpatrywać w aspekcie umownym ${ }^{35}$ (w znaczeniu kontraktu)? Zasadność tak postawionego pytania wynika $\mathrm{z}$ faktu, że za dopuszczalną ${ }^{36}$ należy uznać możliwość zawarcia porozumienia między związkiem zawodowym i pracodawcą o czasowym powstrzymaniu się organizacji związkowej od wywołania sporu zbiorowego ${ }^{37}$, a w konsekwencji strajku. Nie jest to jednak ograniczenie stricte prawa pracowników do strajku, gdyż prawo do strajku przysługuje jako prawo

${ }^{33}$ K.W. Baran, Z problematyki odpowiedzialności cywilnej za nielegalny strajk..., s. 504.

34 B. Cudowski, Odpowiedzialność prawna uczestników nielegalnego strajku - część I, s. 52. Osobą prawną jest tutaj związek zawodowy, a organem osoby prawnej zarząd lub tzw. komitet strajkowy. Szerzej zob. J. Żołyński, Strajk i inne..., s. 358-405.

${ }^{35}$ Problematyka ta nie była dotychczas przedmiotem szerszej analizy normatywnej i doktrynalnej. Na powyższe zagadnienie zwraca uwagę (w zasadzie informacyjnie, przyczynkowo) K.W. Baran, Z problematyki odpowiedzialności cywilnej za nielegalny strajk..., s. 506-507.

${ }^{36}$ Przeciwnikiem zawarcia takiego porozumienia przez związki zawodowe z pracodawcą jest np. K. Rączka, który uznaje, że zobowiązanie związków zawodowych do powstrzymania się od strajku stanowi w istocie ograniczenie pracowniczego prawa, a nie związkowego prawa do akcji strajkowej, K. Rączka, w: Kodeks pracy. Komentarz, M. Gersdorf, K. Rączka, M. Raczkowski (red.), Warszawa 2010, s. 938.

${ }^{37}$ Zob. np. L. Florek, Ustawa i umowa w prawie pracy, Warszawa 2010, s. 261-262. Szerszych rozważań w tym zakresie wraz z przywołaniem poglądów innych autorów dokonuję m.in. w opracowaniu Strajk i inne rodzaje akcji protestacyjnych..., s. 180-199. 
podmiotowe wyłącznie pracownikom, a nie związkom zawodowym, które w tym przypadku są jedynie „narzędziem” w realizacji uprawnień pracowniczych. Pracownicy zatem zachowują prawo do strajku, którego jednak sformalizowanie poprzez działania związków zawodowych zostaje oddalone (przesunięte) w czasie. Zawarcie porozumienia jest rezultatem negocjacji, a więc w swoim charakterze jest to umowa cywilna. Od strony aksjologicznej jest to zatem ochrona swobody uczestniczenia w życiu społecznym i możliwości negocjacyjnego kształtowania relacji w środowisku pracy pomiędzy pracodawcą a reprezentacją załogi.

Rozpatrując zagadnienie odpowiedzialności w ramach reżimu ex contractu, należy zwrócić uwagę, że w przypadku wyrządzenia szkody z tytułu naruszenia postanowień umownych pracodawca może dochodzić stosownego odszkodowania. Przede wszystkim ogólnych podstaw prawnych odszkodowania należy poszukiwać w Konstytucji RP (art. 64 ust. 2), który to przepis nakazuje chronić własnośćs ${ }^{38}$. Tym samym daje podstawę do zastosowania zasady, że wyrządzając szkodę jednemu podmiotowi, sprawca zobowiązany jest do jej naprawienia. Następnie bezpośredniej podstawy odpowiedzialności sprawcy za wyrządzoną szkodę należy poszukiwać w kc (o czym dalej). Osobno należy zwrócić uwagę na to, że strony porozumienia antystrajkowego mogą wprost w umowie przewidzieć możliwość naprawienia szkody, wskazując art. 471 kc. Mogą również ustanowić reżim odpowiedzialności w postaci zapisu o karze umownej (art. 483 kc) ${ }^{39}$. W starszej literaturze przedmiotu wyrażony został także pogląd (który wprawdzie odnosi się do porozumienia zbiorowego $\mathrm{w}$ ogólności, lecz porozumienie antystrajkowe jest porozumieniem zbiorowym ${ }^{40}$ ), iż w przypadku, gdy porozumienie zobowiązuje jedną ze stron do świadczeń pieniężnych (np. do zapłaty określonej kwoty pieniężnej), strony mogą nadać porozumieniu charakter ugody w rozumieniu art. 917-918 kc. W takim razie porozumienie powinno określać termin spełnienia świadczenia, odsetki za zwłokę oraz stwierdzenie, że ugoda będzie tytułem egzekucyjnym, który może być zaopatrzony

${ }^{38}$ Zob. J. Żołyński, Ochrona własności pracodawcy w sporze zbiorowym, Roczniki Administracji i Prawa XV, 2, M. Borski (red.), Sosnowiec 2016.

${ }^{39}$ Z. Salwa wskazuje, odnosząc się wprawdzie do układów zbiorowych pracy, że strony porozumienia mogą zawrzeć postanowienia dotyczące zasad odszkodowania, Z. Salwa, Kodeks pracy po nowelizacji. Komentarz, Warszawa 1996, s. 381-382.

${ }^{40}$ Odnośnie do charakteru prawnego porozumień zbiorowych zob. m.in. J. Żołyński, Porozumienia kończące spór zbiorowy...; G. Goździewicz, Charakter porozumień zbiorowych w prawie pracy, Praca i Zabezpieczenie Społeczne 1998, 3; J. Wratny, Porozumienia zbiorowe - czy dekompozycja prawotwórstwa zakładowego, Praca i Zabezpieczenie Społeczne 2011, 7; L. Florek, Charakter prawny porozumień zbiorowych, w: Prawo pracy. Refleksje i poszukiwania. Ksiega jubileuszowa Profesora Jerzego Wratnego, G. Uścińska (red.), Warszawa 2013; K.W. Baran, Porozumienia zawierane w sporach zbiorowych jako źródła prawa pracy, Monitor Prawa Pracy 2008, 9 czy Tenże, Z problematyki „innych” porozumień zbiorowych, w: Przyszłość prawa pracy. Liber Amicorum. W pięćdziesięciolecie pracy naukowej Profesora Michała Seweryńskiego, Z. Hajna, D. Skupień (red.), Łódź 2015. 
w klauzulę wykonalności w rozumieniu art. 777 pkt 3 Kodeksu postępowania cywilnego $(\mathrm{kpc})^{41}$.

\section{Sposób naprawienia szkody}

Odnosząc się do zagadnienia sposobu naprawienia szkody, należy rozstrzygnąć zakres podmiotowy i przedmiotowy odpowiedzialności.

\section{Zakres podmiotowy odpowiedzialności}

Rozpatrując powyższe zagadnienie, należy wyraźnie stwierdzić, że pracodawca strat poniesionych $w$ wyniku nielegalnego strajku nie może $w$ żaden sposób przenieść (obciążyć) na pracowników. Pracownicy nie ponoszą swoiście rozumianego ryzyka kompensacji, czyli naprawienia szkód, jakie poniósł pracodawca w wyniku tej akcji protestacyjnej. W wymiarze normatywnym pracodawca w przypadku naruszenia umownej klauzuli no-strike będzie uprawniony do dochodzenia roszczeń odszkodowawczych wyłącznie od jej organizatorów. Nie ulega wątpliwości, że podmiotem zobowiązanym po stronie pracowniczej jest wyłącznie związek zawodowy, który złamał zawarte porozumienie. Stroną porozumienia z pracodawcą jest bowiem związek zawodowy, a nie załoga zakładu pracy. W świetle polskich regulacji nie występuje mianowicie odpowiedzialność zbiorowa. Nie można jednak wykluczyć pociągnięcia pracowników do swoiście rozumianej odpowiedzialności pracowniczej (w postaci nałożenia kary porządkowej, wypowiedzenia umowy o pracę lub jej rozwiązania w trybie natychmiastowym), w sytuacji gdy pracodawca wyraźnie poinformował i ostrzegł ich, że strajk jest nielegalny, gdyż zostało naruszone porozumienie umowne. Wymagane byłoby jednak, moim zdaniem, wykazanie każdemu pracownikowi przez pracodawcę winy umyślnego udziału w strajku. Pracownik bowiem pojedynczo nie występuje przeciwko zasadzie pokoju społecznego, jednakże - należąc do związku zawodowego - powinien zaniechać stosowania środków nacisku na pracodawcę ${ }^{42}$, który „uświadomił” mu nielegalność takiego zachowania.

Konsekwencją wyłącznej odpowiedzialności organizatorów nielegalnego strajku jest także to, że pracodawca nie posiada legitymacji prawnej do zobowiązania pracowników do pracy w czasie ponadwymiarowym w celu „wyrównania” poniesionych strat. Byłoby to niezgodne $\mathrm{z}$ art. $151 \S 1$ pkt $2 \mathrm{kp}$. Nie można mianowicie na gruncie obowiązującej ustawy o rozwiązywaniu sporów zbiorowych uznać, że „odpracowanie” stanowi szczególnie uzasadnione potrzeby pracodawcy. Należy jednakże zwrócić uwagę na regulację wynikającą $\mathrm{z}$ art. $130 \$ 3 \mathrm{kp}$, zgodnie z którą wymiar czasu pracy

${ }^{41}$ W. Masewicz, Rokowania oraz spory zbiorowe pracy, Biblioteczka Pracownicza, Poradnik nr 26, Warszawa 1993, s. 44.

${ }^{42}$ W literaturze obcej takie stawisko prezentuje F. Gamillscheg, Kolletives Arbeitsrecht..., s. 1080 i n. 
w okresie rozliczeniowym ulega w tym okresie odpowiednio obniżeniu o liczbę godzin usprawiedliwionej nieobecności w pracy. Nielegalny strajk nie jest usprawiedliwioną nieobecnością w pracy. Nieusprawiedliwiona nieobecność w pracy nie obniża ogólnego wymiaru należnego czasu pracy. Pracodawca zatem jest uprawniony do obniżenia wynagrodzenia za nieprzepracowany czas pracy lub może oczekiwać „odpracowania” czasu przypadającego na nielegalny strajk, lecz „nie może jednak polecić odpracowania w okolicznościach przekroczenia norm" ${ }^{\text {43 }}$.

\section{Zakres przedmiotowy odpowiedzialności}

$\mathrm{Z}$ uwagi na to, że szkodę powstałą w wyniku nielegalnego strajku należy traktować jako nierespektowanie zasady pacta sunt servanda, zachodzić będzie reżim odpowiedzialności kontraktowej (art. $471 \mathrm{kc}$ ), a więc naprawienie szkody będzie następować według klasycznych reguł obowiązujących w kc. Szkodą będą nie tylko bezpośrednie wymierne straty (damnum emergens), lecz także ewentualne utracone korzyści (lucrum cessans).

W celu dochodzenia roszczeń odszkodowawczych niezbędne będzie ustalenie winy sprawcy, wysokość szkody oraz związek skutkowo-przyczynowy między szkodą a nielegalną akcją strajkową. W tym przypadku zasadne jest postawienie tezy, że występuje tutaj domniemanie winy organizatorów takiej akcji, przy czym raczej należy mówić o dolus eventualis niż o winie umyślnej. Domniemanie winy należy rozumieć w ten sposób, że indukcyjne rozumowanie prowadzi do wniosku, iż skoro strajk jest nielegalny, gdyż strona związkowa umownie zobowiązała się do powstrzymania się od akcji strajkowej, to powstanie szkody jest konsekwencją takiej akcji. Niemniej ciężar dowodowy, zgodnie $\mathrm{z}$ art. $6 \mathrm{kc}$, spoczywać będzie na pracodawcy.

Teoretycznie, zgodnie z regułami prawa cywilnego, poszkodowany uprawniony jest do wyboru sposobu naprawienia szkody. Może zatem dochodzić naprawienia szkody w postaci żądania zapłaty odpowiedniej sumy pieniężnej lub żądania przywrócenia stanu poprzedniego (art. $363 \mathrm{kc}$ ). Nie jest to bowiem szkoda wynikająca ze stosunku pracy (regulowana kp), lecz szkoda dochodzona według wspomnianych już reguł kc. Z uwagi na uwarunkowania wynikające z charakteru szkody i podmiotu, który ją wyrządza, pracodawca może w zasadzie dochodzić jej naprawienia poprzez zapłatę odpowiedniej sumy pieniężnej. W specyficznym rozumieniu przywrócenie stanu poprzedniego może mieć miejsce jedynie, gdy pracownicy wyrównają szkodę poprzez świadczenie pracy w nominalnym czasie pracy, choć w aspekcie psychologiczno-fizycznym może to być trudne do realizacji. Jednakże oparciem normatywnym może być art. $83 \$ 3 \mathrm{kp}$, „przewidujący” zwiększenie osobistego wkładu pracy pracowników lub zwiększenie ich sprawności zawodowej ${ }^{44}$.

43 A. Sobczyk, w: Kodeks pracy. Komentarz, D. Dörre-Kolasa, M. Gładoch, P. Korus, L. Mitrus, A. Sobczyk, J. Stelina, M. Zieleniecki, (red.), Warszawa 2014, s. 560.

${ }^{44}$ W przedmiotowym zakresie zob. J. Żołyński, Aksjologiczne, normatywne i społeczne..., s. 120-123. 


\section{Odpowiedzialność na tle regulacji Unii Europejskiej}

Rozpatrując odpowiedzialność organizatorów strajku w świetle regulacji polskich, niepełne byłoby pozostawienie tego zagadnienia bez odniesienia się do regulacji Unii Europejskiej, a w szczególności do stanowiska prezentowanego przez Trybunał Sprawiedliwości Unii Europejskiej. Otóż istotne w orzeczeniach trybunału jest to, że należy mieć na uwadze adekwatność zastosowanych środków w odniesieniu do zamierzonych celów, a więc trybunał uznaje potrzebę stosowania zasady proporcjonalności w zbiorowym prawie pracy. Stąd legalność działań zbiorowych zależy od tego, czy podjęte działania są odpowiednie do zamierzonych celów i nie wykraczają ponad to, co jest konieczne ${ }^{45}$. Uzasadnione jest zatem postawienie tezy, że przekroczenie ograniczenia wyznaczonego dla konkretnej akcji protestacyjnej (a na takie ograniczenie związki zawodowe wyrażają zgodę, podpisując porozumienie o czasowym zawieszeniu prawa do strajku) uprawnia w świetle prawa wspólnotowego do tzw. effective remedies. W rezultacie oznacza to możliwość dochodzenia od organizatorów takiej akcji odszkodowania za doznanie szkody nie tylko w zwykłych granicach (damnum emergens), lecz także utraconych korzyści (lucrum cessans) ${ }^{46}$. Stanowi to więc obowiązek wyrównania szkody, co jest wyrazem ochrony prawa własności. Obowiązek naprawienia szkody stanowi także przejaw ochrony wolności gospodarczej. Trybunał uznał mianowicie, że wolności gospodarcze stanowią pełnoprawne prawo podstawowe ${ }^{47}$, na które wprost mogą powoływać się zarówno państwa członkowskie czy władze publiczne, lecz - co jest szczególnie istotne - także osoby prywatne. Mają zatem wymiar horyzontalny erga omnes. Wobec powyższego są to prawa, które muszą znajdować się pod ochroną i podlegać gwarancjom czynionym przez państwo i zasługują na ochronę nie tylko w zakresie relacji publicznoprawnych, lecz również w stosunkach prawnych będących domeną prawa prywatnego ${ }^{48}$.

${ }_{45}$ Zob. także U. Doniec, Wplyw orzeczeń Europejskiego Trybunału Sprawiedliwości w sprawach Viking (C-438/05) i Laval (C-341/05) na prawo Austrii - analiza raportu prof. Konrada Grillbergera oraz Eliasa Feltena, Studia z Zakresu Prawa Pracy i Polityki Społecznej, A. Świątkowski (red.), Kraków 2010.

${ }^{46}$ Myśl zaczerpnięta z opracowania K. Franczak, Analiza stanowiska przedstawiciela Włoch Giovanniego Orlandini dotyczacego wyroku Trybunatu Sprawiedliwości Wspólnot Europejskich z siedzibq w Luksemburgu w sprawach Viking i Laval z grudnia 2007 r., Studia z Zakresu Prawa Pracy i Polityki Społecznej, A. Świątkowski (red.), Kraków 2010, s. 234.

${ }^{47}$ Niemniej należy zauważyć, że np. we Włoszech wolności ekonomiczne pracodawcy korzystają z większej ochrony niż akcje zbiorowe (K. Franczak, Analiza stanowiska przedstawiciela Włoch..., s. 232), a w prawie brytyjskim protest pracowniczy rozumiany jest bardzo restrykcyjnie, gdyż co do zasady wszystkie formy protestu pracowniczego w Wielkiej Brytanii uznawane są za nielegalne, a ustawowa ochrona dotyczy tylko niektórych rodzajów protestu (A. Kornecka, Wplyw orzeczeń Europejskiego Trybunatu Sprawiedliwości w sprawach Laval (C-341/05) i Viking (C 438/05) na prawo pracy w Wielkiej Brytanii w świetle komentarza prof. Eriki Czyszczak, Studia z Zakresu Prawa Pracy i Polityki Społecznej, A. Świątkowski (red.), Kraków 2010, s. 240).

${ }^{48}$ K. Franczak, Analiza stanowiska przedstawiciela Włoch..., s. 231-232. 


\section{Uwagi końcowe}

Przeprowadzone w niniejszej syntezie rozumowanie prowadzi do wniosku, że od strony normatywnej organizatorzy nielegalnego strajku za szkody nim wyrządzone ponoszą nie tylko odpowiedzialność cywilną na zasadach deliktowych, lecz może to być odpowiedzialność, która jest wynikiem złamania zasady pacta sunt servanda. Jest to zatem odpowiedzialność:

- odpowiedzialność kontraktowa;

- o charakterze odpowiedzialności subsydiarnej w stosunku do odpowiedzialności wynikającej z ustawy o rozwiązywaniu sporów zbiorowych;

- ze sfery prawa prywatnego - Kodeksu cywilnego, a nie ze sfery prawa publicznego - regulowanego ustawą o rozwiązywaniu sporów zbiorowych;

- de lege lata pracodawca ma w zasadzie do organizatorów strajku jedynie roszczenie o naprawienie szkody wyłącznie poprzez żądanie zapłaty kwoty pieniężnej;

- a pracodawca może poniekąd „zobowiązać” strajkujących pracowników do odpracowania czasu nielegalnego strajku na podstawie art. $83 \$ 3 \mathrm{kp}$, lecz wyłącznie w nominalnym czasie pracy.

\section{Bibliografia}

Baran K.W., Z problematyki odpowiedzialności cywilnej za nielegalny strajk lub inna akcje protestacyjna, w: Prawo pracy wświetle procesów integracji europejskiej. Księga jubileuszowa Profesor Marii Matey-Tyrowicz, J. Wratny, M.B. Rycak (red.), Warszawa 2011.

Baran K.W., Porozumienia zawierane w sporach zbiorowych jako źródła prawa pracy, Monitor Prawa Pracy 2008, 9.

Baran K.W., Z problematyki ,innych" porozumień zbiorowych, w: Przyszłość prawa pracy. Liber Amicorum. W pięćdziesięciolecie pracy naukowej Profesora Michała Seweryńskiego, Z. Hajna, D. Skupień (red.), Łódź 2015.

Birk R., Industrial Conflict. The Law of Stres and Lock-out, w: Comparative Labour Law and Industrial Relations, R. Blanpain (red.), Deventer, The Netherland 1985.

Chabrowska A., Odpowiedzialność pracownika za zorganizowanie i udział w nielegalnym strajku, w: Z problematyki prawa pracy i polityki społecznej, A. Nowak (red.), t. 11, Katowice 1994.

Cudowski B., Odpowiedzialność prawna uczestników nielegalnego strajku - część I, Praca i Zabezpieczenie Społeczne 1996, 2 i część II, Praca i Zabezpieczenie Społeczne 1996, 3.

Doniec U., Wplyw orzeczeń Europejskiego Trybunału Sprawiedliwości w sprawach Viking (C-438/05) i Laval (C-341/05) na prawo Austrii - analiza raportu prof. Konrada Grillbergera oraz Eliasa Feltena, Studia z Zakresu Prawa Pracy i Polityki Społecznej, A. Świątkowski (red.), Kraków 2010.

Florek L., Ustawa i umowa w prawie pracy, Warszawa 2010. 
Florek L., Charakter prawny porozumień zbiorowych, w: Prawo pracy. Refleksje i poszukiwania. Ksiega jubileuszowa Profesora Jerzego Wratnego, G. Uścińska (red.), Warszawa 2013.

Franczak K., Analiza stanowiska przedstawiciela Włoch - Giovanniego Orlandini dotyczacego wyroku Trybunału Sprawiedliwości Wspólnot Europejskich z siedziba w Luksemburgu w sprawach Viking i Laval z grudnia 2007 r., Studia z Zakresu Prawa Pracy i Polityki Społecznej, A. Świątkowski (red.), Kraków 2010.

Franzen M., Erfurter Kommentar zum Arbeitsrecht, Munchen 2012.

Gamillscheg F., Kolletives Arbeitsrecht. Ein Lehrbuch. Band I: Grundlagen/Koalitionsfreiheit/ Tarifvertrag. Arbeitskampf und Schlichtung, Munchen 1997.

Gardawski J., Na dwudziestolecie dialogu społecznego w Polsce, w: Zbiorowe prawo pracy w XXI wieku, A. Wypych-Żywicka, M. Tomaszewska, J. Stelina (red.), Gdańsk 2010.

Goździewicz G., Charakter porozumień zbiorowych w prawie pracy, Praca i Zabezpieczenie Społeczne 1998, 3.

Kloc K., Konflikty przemysłowe, spory zbiorowe i mediacje, w: Zbiorowe stosunki pracy w Polsce w perspektywie integracji europejskiej, W. Kozaczek (red.), Warszawa 1997.

Kornecka A., Wpływ orzeczeń Europejskiego Trybunału Sprawiedliwości w sprawach Laval (C-341/05) i Viking (C 438/05) na prawo pracy w Wielkiej Brytanii w świetle komentarza prof. Eriki Czyszczak, Studia z Zakresu Prawa Pracy i Polityki Społecznej, A. Świątkowski (red.), Kraków 2010.

Masewicz W., Ustawa z dnia 23 maja 1991 r. o rozwiązywaniu sporów zbiorowych. Komentarz, Warszawa 1992.

Masewicz W., Rokowania oraz spory zbiorowe pracy, Biblioteczka Pracownicza, Poradnik nr 26, Warszawa 1993.

Rączka K., w: Kodeks pracy. Komentarz, M. Gersdorf, K. Rączka, M. Raczkowski (red.), Warszawa 2010.

Salwa Z., Kodeks pracy po nowelizacji. Komentarz, Warszawa 1996.

Sanetra W., Dialog społeczny jako element ustroju społecznego i politycznego w świetle Konstytucji $R P, \mathrm{w}$ : Zbiorowe prawo pracy w XXI wieku, A. Wypych-Żywicka, M. Tomaszewska, J. Stelina (red.), Gdańsk 2010.

Schülter W., Prawo zbiorowych sporów pracowniczych w RFN, Studia Prawnicze 1991, 1.

Skrzydło W., Komentarz do art. 2 Konstytucji Rzeczypospolitej Polskiej, LEX.

Sobczyk A., Wolność pracy i władza, Warszawa 2015.

Sobczyk A., w: Kodeks pracy. Komentarz, D. Dörre-Kolasa, M. Gładoch, P. Korus, L. Mitrus, A. Sobczyk, J. Stelina, M. Zieleniecki (red.), Warszawa 2014.

Świątkowski A.M., Gwarancje prawne pokoju społecznego w stosunkach pracy, Warszawa 2013.

Swiątkowski A., The Social Peace Obligation During the Period of Transition from a Planned to a Market Ekonomy, w: Liber Amicorum for Clyde W. Summers. The Changing Face of Labour Law and Industrial Relations, Nemes Verlegsgessellschaff, R. Blanpain, M. Weiss (red.), Baden-Baden 1993.

Świątkowski A., Rozwiązywanie sporów zbiorowych, Studia z Zakresu Prawa Pracy i Polityki Społecznej, Kraków 1994. 
Świda W., Koncepcja „employment at will” w federalnym prawie pracy Stanów Zjednoczonych Ameryki Północnej. Studia z Zakresu Prawa Pracy i Polityki Społecznej, A. Świątkowski (red.), Kraków 2006.

Wagner B., Odpowiedzialność za zorganizowanie i udział w nielegalnym strajku, Praca i Zabezpieczenie Społeczne 1992, 1.

Wratny J., Porozumienia zbiorowe - czy dekompozycja prawotwórstwa zakładowego, Praca i Zabezpieczenie Społeczne 2011, 7.

Wypchło B., Idea zachowania pokoju społecznego $w$ zbiorowych stosunkach pracy $-w$ Polsce i w krajach demokracji zachodniej, Studia z Zakresu Prawa Pracy i Polityki Społecznej, t. I, A. Świątkowski (red.), Kraków 1994.

Wypchło-Grymek B., Prawne uregulowania w przedmiocie sporów zbiorowych pracy a zasada zachowania pokoju społecznego, Studia z Zakresu Prawa Pracy i Polityki Społecznej, A.M. Świątkowski (red.), Kraków 1996.

Zakładowy dialog społeczny, J. Stelina (red.), Warszawa 2013.

Zieliński T., Nowy ład pracy - rzeczywistość i wizja przyszłości, w: Nowy ład pracy w Polsce i w Europie, M. Matey (red.), Warszawa 1997.

Żołyński J., Aksjologiczne, normatywne i społeczne podstawy prawa rozwiązywania sporów zbiorowych pracy, Gdańsk 2016.

Żołyński J., Strajk $i$ inne rodzaje akcji protestacyjnych jako metody rozwiązywania sporów zbiorowych, Warszawa 2013.

Żołyński J., Spór zbiorowy a obowiązywanie układu zbiorowego pracy. Zasada zachowania pokoju społecznego, w: Układy zbiorowe pracy. W stulecie urodzin Profesora Wacława Szuberta, Z. Góral (red.), Warszawa 2013.

Żołyński J., O pojęciu wspólnoty załogi w prawie pracy, Studia z Zakresu Prawa Pracy i Polityki Społecznej, K.W. Baran (red.), Kraków 2017.

Żołyński J., Porozumienia kończące spór zbiorowy jako „swoiste” źródła prawa pracy, Studia z Zakresu Prawa Pracy i Polityki Społecznej, A. Świątkowski (red.), Kraków 2013.

Żołyński J., Ochrona własności pracodawcy w sporze zbiorowym, Roczniki Administracji i Prawa, XV, z. 2, M. Borski (red.), Sosnowiec 2016. 